Article

\title{
Enrichment of Zinc and Iron Micronutrients in Lentil (Lens culinaris Medik.) through Biofortification
}

\author{
Salwinder Singh Dhaliwal ${ }^{1}{ }^{(0)}$, Vivek Sharma ${ }^{1}{ }^{(D}$, Arvind Kumar Shukla ${ }^{2}{ }^{\circledR}$, Janpriya Kaur ${ }^{1}$, Vibha Verma ${ }^{1}$, \\ Prabhjot Singh ${ }^{1}$, Harkirat Singh ${ }^{1}$, Shams H. Abdel-Hafez ${ }^{3} \mathbb{D}$, Samy Sayed ${ }^{4}\left(\mathbb{D}\right.$, Ahmed Gaber ${ }^{5, *(D)}$, \\ Reham Ali ${ }^{6,7}$ (D) and Akbar Hossain ${ }^{8, *(D)}$
}

1 Department of Soil Science, Punjab Agricultural University, Ludhiana 141004, India; ssdhaliwal@pau.edu (S.S.D.); sharmavivek@pau.edu (V.S.); janpriyakaur89@pau.edu (J.K.); vermavibha@pau.edu (V.V.); prabh@pau.edu (P.S.); dhaliwalss764@gmail.com (H.S.)

2 Indian Institute of Soil Science (IISS), Bhopal 462038, India; arvindshukla2k3@yahoo.co.in

3 Department of Chemistry, College of Science, Taif University, Taif 21944, Saudi Arabia; s.abdelhafez@tu.edu.sa

4 Department of Science and Technology, University College-Ranyah, Taif University, Taif 21944, Saudi Arabia; s.sayed@tu.edu.sa

5 Department of Biology, College of Science, Taif University, Taif 21944, Saudi Arabia

6 Department of Chemistry, College of Science, Qassim University, Buraidah 51452, Saudi Arabia; re.ali@qu.edu.sa

7 Chemistry Department, Science College, Suez University, Suez 43518, Egypt

Citation: Dhaliwal, S.S.; Sharma, V.; Shukla, A.K.; Kaur, J.; Verma, V.; Singh, P.; Singh, H.; Abdel-Hafez, S.H.; Sayed, S.; Gaber, A.; et al. Enrichment of Zinc and Iron Micronutrients in Lentil (Lens culinaris Medik.) through Biofortification. Molecules 2021, 26, 7671. https://doi.org/10.3390/ molecules26247671

Academic Editors: Tuba Esatbeyoglu and Banu Bayram

Received: 18 November 2021 Accepted: 15 December 2021 Published: 18 December 2021

Publisher's Note: MDPI stays neutral with regard to jurisdictional claims in published maps and institutional affiliations.

Copyright: (c) 2021 by the authors. Licensee MDPI, Basel, Switzerland. This article is an open access article distributed under the terms and conditions of the Creative Commons Attribution (CC BY) license (https:// creativecommons.org/licenses/by/ $4.0 /)$.
8 Department of Agronomy, Bangladesh Wheat and Maize Research Institute, Dinajpur 5200, Bangladesh

* Correspondence: a.gaber@tu.edu.sa (A.G.); akbarhossainwrc@gmail.com (A.H.)

\begin{abstract}
Biofortification of pulse crops with $\mathrm{Zn}$ and $\mathrm{Fe}$ is a viable approach to combat their widespread deficiencies in humans. Lentil (Lens culinaris Medik.) is a widely consumed edible crop possessing a high level of $\mathrm{Zn}$ and Fe micronutrients. Thus, the present study was conducted to examine the influence of foliar application of $\mathrm{Zn}$ and Fe on productivity, concentration, uptake and the economics of lentil cultivation (LL 931). For this, different treatment combinations of $\mathrm{ZnSO}_{4} \cdot 7 \mathrm{H}_{2} \mathrm{O}$ $(0.5 \%)$ and $\mathrm{FeSO}_{4} \cdot 7 \mathrm{H}_{2} \mathrm{O}(0.5 \%)$, along with the recommended dose of fertilizer (RDF), were applied to the lentil. The results of study reported that the combined foliar application of $\mathrm{ZnSO}_{4} \cdot 7 \mathrm{H}_{2} \mathrm{O}$ $(0.5 \%)+\mathrm{FeSO}_{4} \cdot 7 \mathrm{H}_{2} \mathrm{O}(0.5 \%)$ at pre-flowering (S1) and pod formation (S2) stages was most effective in enhancing grain and straw yield, $\mathrm{Zn}$ and Fe concentration, and uptake. However, the outcome of this treatment was statistically on par with the results obtained under the treatment $\mathrm{ZnSO}_{4} \cdot 7 \mathrm{H}_{2} \mathrm{O}$ $(0.5 \%)+\mathrm{FeSO}_{4} \cdot 7 \mathrm{H}_{2} \mathrm{O}(0.5 \%)$ at $\mathrm{S} 1$ stage. A single spray of $\mathrm{ZnSO}_{4} \cdot 7 \mathrm{H}_{2} \mathrm{O}(0.5 \%)+\mathrm{FeSO}_{4} \cdot 7 \mathrm{H}_{2} \mathrm{O}(0.5 \%)$ at $\mathrm{S} 1$ stage enhanced the grain and straw yield up to $39.6 \%$ and $51.8 \%$, respectively. Similarly, $\mathrm{Zn}$ and Fe concentrations showed enhancement in grain (10.9\% and $20.4 \%$, respectively) and straw (27.5\% and $27.6 \%$ respectively) of the lentil. The increase in $\mathrm{Zn}$ and Fe uptake by grain was $54.8 \%$ and $68.0 \%$, respectively, whereas uptake by straw was $93.6 \%$ and $93.7 \%$, respectively. Also the benefit:cost was the highest (1.96) with application of $\mathrm{ZnSO}_{4} \cdot 7 \mathrm{H}_{2} \mathrm{O}(0.5 \%)+\mathrm{FeSO}_{4} \cdot 7 \mathrm{H}_{2} \mathrm{O}(0.5 \%)$ at S1 stage. Conclusively, the combined use of $\mathrm{ZnSO}_{4} \cdot 7 \mathrm{H}_{2} \mathrm{O}(0.5 \%)+\mathrm{FeSO}_{4} \cdot 7 \mathrm{H}_{2} \mathrm{O}(0.5 \%)$ at $\mathrm{S} 1$ stage can contribute significantly towards yield, $\mathrm{Zn}$ and Fe concentration, as well as uptake and the economic returns of lentil to remediate the $\mathrm{Zn}$ and Fe deficiency.
\end{abstract}

Keywords: lentil; micronutrient content; foliar application; efficiency indices; economic feasibility

\section{Introduction}

Pulses and legumes belong to the nutritionally rich Fabaceae family and are an important source of plant proteins, having a low glycemic index. Apart from that, they are great reservoirs of vitamins, minerals and complex carbohydrates that are crucial for optimum growth as well as development [1]. Among different food legumes, lentil (Lens culinaris Medik.) is a vital grain legume crop grown worldwide, and is also considered as 
the cheapest source of protein and micronutrients such as $\mathrm{Zn}$ and Fe with the concentrations ranging from $44-54 \mathrm{mg} \cdot \mathrm{kg}^{-1}$ and $73-90 \mathrm{mg} \cdot \mathrm{kg}^{-1}$, respectively [2,3]. However, a wide variation in micronutrient content has been observed among diverse lentil genotypes $[4,5]$. It is a widely used ingredient in many plant-based diets because of its lower-cooking time, and economically available minerals and good-quality proteins $[6,7]$. However, the presence of phytate phosphorus in sufficient amount limits the bioavailability of $\mathrm{Zn}$ and Fe for absorption in humans [8-10]. Moreover, Fe in plants is present as a non-heme in contrast to animal sources, where it is present as heme Fe and thus its bioavailability is relatively lower than animal-based proteins [11].

Intense agricultural activities due to the burgeoning human population have resulted into micronutrient deficiencies in soil. Zinc deficiency is prevalent worldwide, especially in calcareous soils. In India, 51.2 and $19.2 \%$ of soils were found to be deficient in $\mathrm{Zn}$ and $\mathrm{Fe}$, respectively [12]. Micronutrient deficiencies in soils and crops have led to severe consequences, including reduced yield and low micronutrient concentration in crops, thus resulting in micronutrient malnutrition in humans and animals. Worldwide, $\mathrm{Zn}$ and Fe deficiencies have affected one-fifth and one-third of the population, respectively [13]. Zinc deficiency has been observed mainly in developing countries [14]. It is essential for optimum growth and functioning of immune system, enzyme catalyzed biochemical reactions, neurobehavioral development, protein and DNA synthesis [15] and its deficiency results in adverse health conditions such as diarrhea, stunted physical and mental growth, loss of appetite, etc. Iron deficiency results into anemia, which globally has affected 40.0 and $42.0 \%$ of pregnant women and children, respectively, and even resulted to $20.0 \%$ of maternal deaths $[16,17]$. Inadequate $\mathrm{Fe}$ intake causes the increased mortality of pregnant women and newborns and compromises the immune system [18].

Various approaches such as biofortification, nutrient supplementation, fortification, and diet diversification have been implemented in order to overcome micronutrient malnutrition [19]. However, biofortification is considered as a long-term and efficient method over the others due to the lack of socio-economic infrastructure [20-22]. Biofortification also results in better crop productivity and nutritional quality, thus diminishing the micronutrient malnutrition in consumers [23]. Agronomic biofortification refers to the use of mineral fertilizers to improve concentration of nutrients in edible crops and also positively affects the crop yield [24]. The application of fertilizers can be done through soil, seeds and foliar spray; however, foliar application is considered as the best method of increasing the micronutrient level in crops, as nutrients are directed towards the leaves at suitable growth stages. The quick absorption of nutrients promotes nutrient translocations in edible grain parts and avoids nutrient losses in the environment. In addition to this, it promotes plant growth even in less favorable weather conditions.

Several research studies have reported the increase in bioavailability of micronutrients through foliar application. The foliar application of Se at full bloom stage of lentil has been demonstrated to increase the seed Se concentration significantly [25]. Another report has shown the significant positive impact of foliar $\mathrm{Zn}$ application on yield and $\mathrm{Zn}$ concentration of diverse mungbean genotypes [26]. The application of $\mathrm{Zn}$ and Fe sources through foliar spray has proved to be the effective treatment to improve the yield and micronutrient content in rice [27]. Foliar application of $\mathrm{Zn}$ reported a significant improvement in plant height, root length, number of nodules, chlorophyll content and seed yield in lentil [28]. Another study reported the positive effect of $\mathrm{Zn}$ and Fe foliar application on yield attributes of lentil in the soils of Dylaman, Guilan province, Iran [29]. To the best of our knowledge, no work has reported the effect of the combined application of $\mathrm{Zn}$ and Fe on yield, concentration and uptake in lentil in the sandy loam soil of northwestern India. Therefore, the present work was aimed at assessing the influence of foliar application of $\mathrm{Zn}$ and $\mathrm{Fe}$ on yield, concentration, their uptake, efficiency indices and economic outcomes from lentil cultivation. 


\section{Materials and Methods}

\subsection{Experimental Site and Characteristics}

The two-year experiment (2019-2020 and 2020-2021) was conducted during Rabbi season (November-April) at the experimental farm, Department of Soil Science, Punjab Agricultural University, Ludhiana, Punjab. The research trial was conducted under the biofortification mandate of AICRP-MSN project, fully funded by IISS (ICAR), Bhopal, India. The sandy loam soil of this experimental field exhibited a $\mathrm{pH}$ of 7.21, electrical conductivity (EC ) $0.34 \mathrm{dS} \cdot \mathrm{m}^{-1}$ and organic carbon (OC) $0.31 \%$. The initial level of diethylene triamime penta acetic acid (DTPA) -extractable micronutrients viz. $\mathrm{Zn}, \mathrm{Cu}, \mathrm{Fe}$ and $\mathrm{Mn}$ in soil were $1.16,0.65,4.86$ and $3.91 \mathrm{mg} \cdot \mathrm{kg}^{-1}$, respectively. The climate in the region is subtropical, with hot, wet summers and dry winters. The annual rainfall of 400-600 mm was observed with the months of July to September receiving the majority of the rainfall, which is approximately $70 \%$ of the total. The total rainfall during the crop season from October to April was 219 and $68.9 \mathrm{~mm}$ during 2019-2020 and 2020-2021, respectively. During the growth season of lentil, the average monthly maximum temperature in the study region varied between $15.9^{\circ} \mathrm{C}$ and $32.8^{\circ} \mathrm{C}$ in $2019-2020$ and $16.4^{\circ} \mathrm{C}$ and $34.2^{\circ} \mathrm{C}$ in $2020-2021$, but the minimum temperature varied between $6.7^{\circ} \mathrm{C}$ and $18.4^{\circ} \mathrm{C}$ in $2019-2020$ and $7.1^{\circ} \mathrm{C}$ and $17.0^{\circ} \mathrm{C}$ in $2020-2021$ (Figure 1).

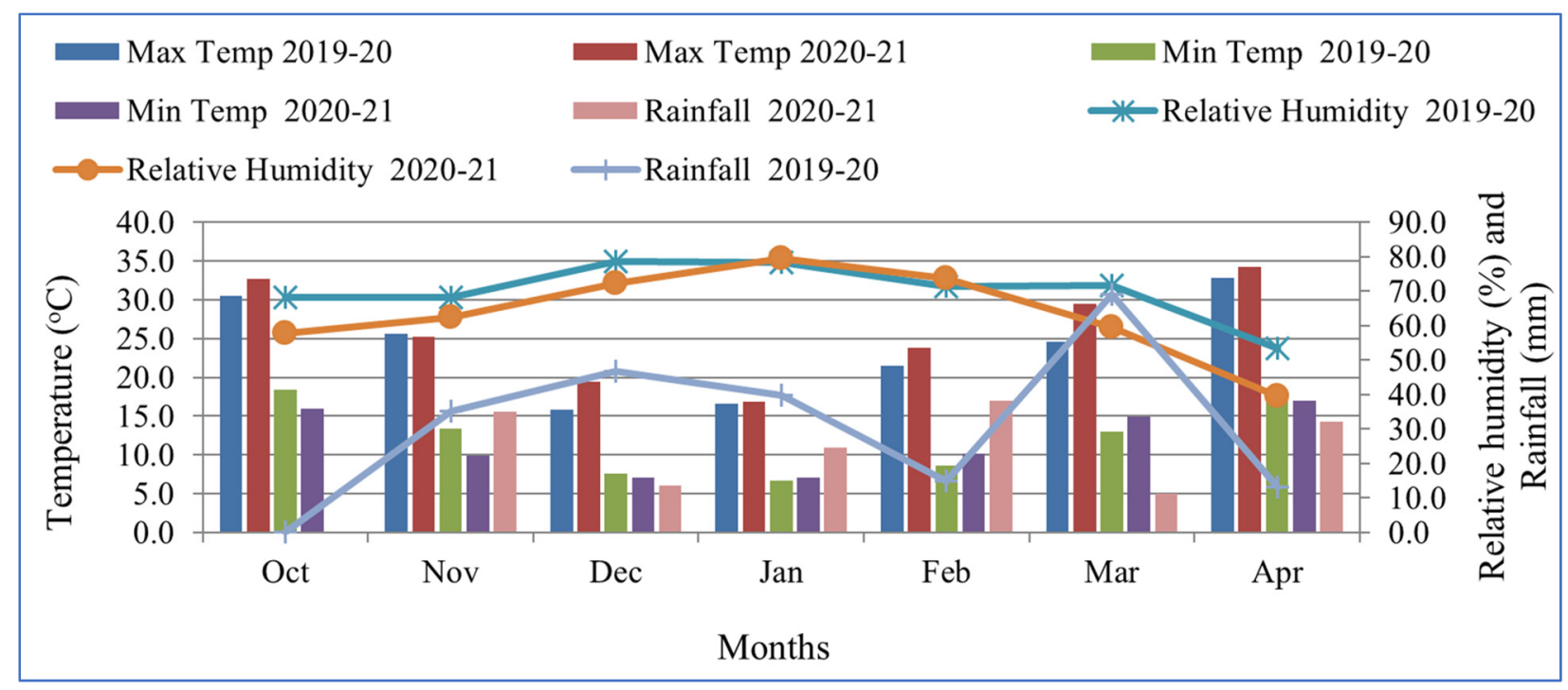

Figure 1. Monthly average maximum and minimum temperature, relative humidity and rainfall of the study area.

\subsection{Treatment Details}

The study involved different combinations of $\mathrm{RDF}$ with $\mathrm{ZnSO}_{4} .7 \mathrm{H}_{2} \mathrm{O}(0.5 \%)$ and $\mathrm{FeSO}_{4} .7 \mathrm{H}_{2} \mathrm{O}(0.5 \%)$ i.e., $1.25 \mathrm{~kg} \cdot \mathrm{ha}^{-1}$ fertilizer applied at pre-flowering (S1) and pod formation (S2) stages i.e., 80 and 100 days after sowing, respectively. For fertilizer application, $250 \mathrm{~L} \cdot \mathrm{ha}^{-1}$ water was used, thus, $1.25 \mathrm{~kg} \cdot \mathrm{ha}^{-1}$ fertilizer was applied for each $0.5 \%$ fertilizer application. In total, seven treatments were involved along with three replications in a complete randomized block design. The treatment details are as follows (Table 1). The field was plowed twice followed by planking. Nitrogen and $\mathrm{P}_{2} \mathrm{O}_{5}$ with the recommended doses of $12 \mathrm{~kg} \cdot \mathrm{ha}^{-1}$ and $40 \mathrm{~kg} \cdot \mathrm{ha}^{-1}$, respectively, were applied as basal doses through urea, diammonium phosphate at the time of sowing. The variety LL 931 was sown in the first week of November, whereas the harvesting was carried out in April (third week). The sowing was performed by the pora method with row to row spacing of $22.5 \mathrm{~cm}$ and plot size $3 \mathrm{~m} \times 3.2 \mathrm{~m}$. 
Table 1. Treatment details of the experimental field at the time of sowing of lentil.

\begin{tabular}{ccc}
\hline SL. No & Treatments & Stage of Application \\
\hline $\mathrm{T}_{1}$ & $\mathrm{RDF}($ control) & \\
$\mathrm{T}_{2}$ & $\mathrm{RDF}+\mathrm{ZnSO}_{4} .7 \mathrm{H}_{2} \mathrm{O}(0.5 \%)$ foliar spray & $\mathrm{S} 1$ * \\
$\mathrm{T}_{3}$ & $\mathrm{RDF}+\mathrm{FeSO}_{4} \cdot 7 \mathrm{H}_{2} \mathrm{O}(0.5 \%)$ foliar spray & $\mathrm{S} 1$ \\
$\mathrm{~T}_{4}$ & $\mathrm{RDF}+\mathrm{ZnSO}_{4} .7 \mathrm{H}_{2} \mathrm{O}(0.5 \%)+\mathrm{FeSO}_{4} \cdot 7 \mathrm{H}_{2} \mathrm{O}$ & $\mathrm{S} 1$ \\
$\mathrm{~T}_{5}$ & $(0.5 \%)$ foliar spray & $\mathrm{S} 1+\mathrm{S} 2$ ** \\
$\mathrm{T}_{6}$ & $\mathrm{RDF}+\mathrm{ZnSO}_{4} \cdot 7 \mathrm{H}_{2} \mathrm{O}(0.5 \%)$ foliar spray & $\mathrm{S} 1+\mathrm{S} 2$ \\
$\mathrm{~T}_{7}$ & $\mathrm{RDF}+\mathrm{FeSO}_{4} \cdot 7 \mathrm{H}_{2} \mathrm{O}(0.5 \%)$ foliar spray & $\mathrm{S} 1+\mathrm{S} 2$ \\
\hline RDF $=$ Recommended Dose of Fertilizers $\left(\mathrm{N}: 12 \mathrm{~kg} \cdot \mathrm{ha}^{-1}, \mathrm{P}_{2} \mathrm{O}_{5}: 40 \mathrm{~kg} \cdot \mathrm{ha}^{-1}\right) ;{ }^{*}$ Pre-flowering ${ }^{* *}$ Pod formation.
\end{tabular}

\subsection{Plant Harvesting and Analysis}

Plants were harvested manually when they attained physiological maturity followed by the collection of grain and straw samples for analysis (500-550 plants per plot). The samples were air-dried before drying in an oven at $65^{\circ} \mathrm{C}$ for $48 \mathrm{~h}$ in order to determine the dry weights of plant components. Oven-dried plant samples were further grounded to fine material using a mechanical grinder. A representative grounded straw sample of $1.0 \mathrm{~g}$ and grain sample of $0.5 \mathrm{~g}$ were digested using a di-acid mixture comprising of $\mathrm{HNO}_{3}$ and $\mathrm{HClO}_{4}$ acid in ratio 3:1 on an electric hot plate [30]. The micronutrients (Fe, $\mathrm{Mn}, \mathrm{Zn}$ and $\mathrm{Cu}$ ) concentration in the digested plant extracts was determined through atomic absorption spectrophotometer (Model AAS 240 FS, Varian, München, Germany). The uptake of micronutrients by lentil grains and straw was calculated by using following equation.

Fe uptake in grain or straw $\left(\mathrm{g} \cdot \mathrm{ha}^{-1}\right)=\frac{\text { Yield }\left(\mathrm{kg} \cdot \mathrm{ha}^{-1}\right) \times \text { Concentration }\left(\mathrm{mg} \cdot \mathrm{kg}^{-1}\right)}{10^{3}}$

\subsection{Zn and Fe Use Efficiency Indices}

The mobilization efficiency index (MEI) was calculated by using the following equation:

$$
M E I=\frac{\text { Nutrient concentartion in grain }}{\text { Nutrient concentration in straw }}
$$

The physiological efficiency of $\mathrm{Zn}$ and $\mathrm{Fe}$ viz. $\left(\mathrm{PE}_{\mathrm{Zn}}\right),\left(\mathrm{PE}_{\mathrm{Fe}}\right)$, the apparent recovery efficiency of Zn (ARE-Zn), Fe (ARE-Fe) and the mobilization efficiency index (MEI-Zn), (MEI-Fe) of foliar-applied $\mathrm{Zn}$ and Fe were determined with the following equations [31].

$$
\begin{gathered}
P E=\frac{Y_{t}-Y_{c}}{N U_{t}-N U_{c}} \\
A R E=\frac{N U_{t}-N U_{c}}{\text { Nutrient applied }\left(\mathrm{kg} \cdot \mathrm{ha}^{-1}\right)} \times 100
\end{gathered}
$$

where $Y_{t}$ and $Y_{c}$ represent the grain yield $\left(\mathrm{kg} \cdot \mathrm{ha}^{-1}\right)$ of lentil in fertilized plots and in control, respectively; $N U_{t}$ and $N U_{c}$ represent the total nutrient $(\mathrm{Zn}, \mathrm{Fe})$ uptake $\left(\mathrm{kg} \cdot \mathrm{ha}^{-1}\right)$ of lentil in fertilized plots and in control, respectively.

\subsection{Economic Analysis}

The cost of fertilizer in US dollars (USD) $\mathrm{ha}^{-1}$ for various treatments in the experiment was calculated separately, considering the prevailing prices of fertilizers in USD at the time of their use. The price of $\mathrm{ZnSO}_{4} .7 \mathrm{H}_{2} \mathrm{O}(0.5 \%)$ and $\mathrm{FeSO}_{4} .7 \mathrm{H}_{2} \mathrm{O}(0.5 \%)$ were $6.67 \mathrm{USD} \mathrm{kg}^{-1}$ and $8.01 \mathrm{USD} \cdot \mathrm{kg}^{-1}$, respectively. The price of seed and the selling price were taken as $1.60 \mathrm{USD} \cdot \mathrm{kg}^{-1}$ and $0.80 \mathrm{USD} \cdot \mathrm{kg}^{-1}$, respectively, whereas the standard labour cost was 4.94 USD. Gross return (value of additional yield) was calculated based on the MSP (price 
for minimum support) of lentil by the Indian government during the years of study. Net return (USD $\cdot$ ha $^{-1}$ ) was obtained by subtracting the fertilizer cost from the gross return as given below.

Net Return $\left(\right.$ USD $\left.\mathrm{ha}^{-1}\right)=$ Gross return $\left(\mathrm{USD} \cdot \mathrm{ha}^{-1}\right)-$ Cost of cultivation $\left(\mathrm{USD} \cdot \mathrm{ha}^{-1}\right.$ )

$\mathrm{B}: \mathrm{C}$ ratio was calculated by using the following equation:

$$
\mathrm{B}: \mathrm{C} \text { ratio }=\frac{\text { Gross return }\left(\mathrm{USD} \cdot \mathrm{ha}^{-1}\right)}{\text { Cost of cultivation }\left(\mathrm{USD} \cdot \mathrm{ha}^{-1}\right)}
$$

\subsection{Statistical Analysis}

The data was analysed using SPSS version 16.0 (SPSS Inc., Chicago, IL, USA) packages. Analysis of variance (ANOVA) followed by a Duncan Multiple Range test was performed to test the significant difference between the treatment results.

\section{Results}

\subsection{Impact of Foliar Application of Zn and Fe on Grain and Straw Yield of Lentil}

The two-year mean data demonstrated that the foliar application of $\mathrm{Zn}$ and Fe at S1 + S2 stages posed a significant impact on grain and straw yield of lentil (Table 2).

Table 2. Effect of biofortification on grain and straw yield of lentil.

\begin{tabular}{|c|c|c|c|c|c|c|}
\hline \multirow{2}{*}{ Treatments } & \multicolumn{3}{|c|}{ Grain Yield $\left(\mathrm{kg} \cdot \mathrm{ha}^{-1}\right)$} & \multicolumn{3}{|c|}{ Straw Yield $\left(\mathrm{kg} \cdot \mathrm{ha}^{-1}\right)$} \\
\hline & Year I & Year II & Mean & Year I & Year II & Mean \\
\hline $\mathrm{T} 1$ & $686^{\mathrm{d}} \pm 24$ & $690^{d} \pm 27$ & $688^{c} \pm 35$ & $2139^{d} \pm 101$ & $2194^{d} \pm 99$ & $2166^{\mathrm{d}} \pm 94$ \\
\hline $\mathrm{T} 2$ & $710^{\mathrm{cd}} \pm 37$ & $740^{\mathrm{d}} \pm 31$ & $725^{c} \pm 38$ & $2277^{\mathrm{d}} \pm 105$ & $2560^{c} \pm 126$ & $2417^{\mathrm{cd}} \pm 103$ \\
\hline $\mathrm{T} 3$ & $906^{\mathrm{ab}} \pm 43$ & $860^{c} \pm 42$ & $883^{b} \pm 41$ & $2918^{b c} \pm 145$ & $2780^{b c} \pm 123$ & $2849^{b} \pm 138$ \\
\hline $\mathrm{T} 4$ & $952^{\mathrm{a}} \pm 41$ & $970^{\mathrm{ab}} \pm 48$ & $961^{\mathrm{a}} \pm 47$ & $3289^{a b} \pm 152$ & $3280^{\mathrm{a}} \pm 159$ & $3290^{a} \pm 161$ \\
\hline $\mathrm{T} 5$ & $782^{\mathrm{bcd}} \pm 32$ & $920^{b} \pm 35$ & $851^{b} \pm 36$ & $2459^{\mathrm{cd}} \pm 96$ & $2925^{b} \pm 134$ & $2692^{b c} \pm 145$ \\
\hline T6 & $926^{\mathrm{ab}} \pm 39$ & $940^{\mathrm{ab}} \pm 47$ & $933^{\mathrm{ab}} \pm 43$ & $3206^{\mathrm{ab}} \pm 139$ & $3370^{a} \pm 162$ & $3288^{a} \pm 138$ \\
\hline $\mathrm{T} 7$ & $994^{\mathrm{a}} \pm 45$ & $980^{a} \pm 33$ & $987^{\mathrm{a}} \pm 34$ & $3609^{a} \pm 163$ & $3469^{a} \pm 148$ & $3539^{a} \pm 159$ \\
\hline $\operatorname{LSD}(p \leq 0.05)$ & 155 & 55 & 94 & 474 & 284 & 324 \\
\hline
\end{tabular}

Treatments details are available in Table 1; Year I, 2019-2020; Year II, 2020-2021; The data in table represents the mean value of three replications; The values having identical superscript letter do not differ significantly at the $5 \%$ level by Duncan's Multiple Range test.

The highest value of grain yield was recorded in treatment T7 $\left(987 \mathrm{~kg} \cdot \mathrm{ha}^{-1}\right)$, which was not statistically different with the results of treatments T4 $\left(961 \mathrm{~kg} \cdot \mathrm{ha}^{-1}\right)$ and T6 $\left(933 \mathrm{~kg} \cdot \mathrm{ha}^{-1}\right)$. The minimum value of grain yield was observed in treatment T1 $\left(688 \mathrm{~kg} \cdot \mathrm{ha}^{-1}\right)$, which was not statistically different with treatment T2 $\left(725 \mathrm{~kg} \cdot \mathrm{ha}^{-1}\right)$. In case of straw yield, the highest value of two years of mean data was achieved in treatment T7 $\left(3539 \mathrm{~kg} \cdot \mathrm{ha}^{-1}\right)$, which was not statistically different from treatments T4 $\left(3290 \mathrm{~kg} \cdot \mathrm{ha}^{-1}\right)$ and T6 $\left(3288 \mathrm{~kg} \cdot \mathrm{ha}^{-1}\right)$, whereas the minimum straw yield was observed in treatment $\mathrm{T} 1\left(2166 \mathrm{~kg} \cdot \mathrm{ha}^{-1}\right)$, which was not statistically different with treatment T2 $\left(2417 \mathrm{~kg} \cdot \mathrm{ha}^{-1}\right)$. Thus, statistically, foliar application of $\mathrm{ZnSO}_{4} .7 \mathrm{H}_{2} \mathrm{O}(0.5 \%)+\mathrm{FeSO}_{4} .7 \mathrm{H}_{2} \mathrm{O}(0.5 \%)$ was equally effective at enhancing the grain and straw yield of lentil as $\mathrm{FeSO}_{4} .7 \mathrm{H}_{2} \mathrm{O}(0.5 \%)$ at $\mathrm{S} 1+\mathrm{S} 2$ stages as well as $\mathrm{ZnSO}_{4} .7 \mathrm{H}_{2} \mathrm{O}$ $(0.5 \%)+\mathrm{FeSO}_{4} .7 \mathrm{H}_{2} \mathrm{O}(0.5 \%)$ at S1. Also, the foliar application of $\mathrm{ZnSO}_{4} .7 \mathrm{H}_{2} \mathrm{O}(0.5 \%)$ along with RDF at $\mathrm{S} 1$ did not significantly affect the grain and straw yield of lentil.

\subsection{Impact of Biofortification on Grain $\mathrm{Zn}$ and Fe Concentration of Lentil}

The two-year data for grain $\mathrm{Zn}$ and Fe concentration in lentil in response to foliar application of $\mathrm{Zn}$ and $\mathrm{Fe}$ at various stages of growth is given in Table 3. The results demonstrated that foliar application of $\mathrm{Zn}$ and Fe at S1 + S2 stages significantly enhanced the $\mathrm{Zn}$ and Fe concentration in lentil over the control. The results of grain $\mathrm{Zn}$ concentration 
in lentil suggested that treatment T7 $\left(66.4 \mathrm{mg} \cdot \mathrm{kg}^{-1}\right)$ was most effective in comparison to treatment T1, in which the least value of grain $\mathrm{Zn}$ concentration $\left(55.9 \mathrm{mg} \cdot \mathrm{kg}^{-1}\right)$ was observed. Thus, foliar application of $\mathrm{ZnSO}_{4} .7 \mathrm{H}_{2} \mathrm{O}(0.5 \%)+\mathrm{FeSO}_{4} .7 \mathrm{H}_{2} \mathrm{O}(0.5 \%)$ along with $\mathrm{RDF}$ at $\mathrm{S} 1+\mathrm{S} 2$ stages was most effective to enhance the grain $\mathrm{Zn}$ concentration in lentil. The results of grain $\mathrm{Fe}$ concentration in lentil demonstrated that the maximum Fe concentration was recorded in treatment T7 $\left(82.9 \mathrm{mg} \cdot \mathrm{kg}^{-1}\right)$, which was not statistically different with treatment $\mathrm{T} 4\left(78.9 \mathrm{mg} \cdot \mathrm{kg}^{-1}\right)$ and $\mathrm{T} 6\left(77.6 \mathrm{mg} \cdot \mathrm{kg}^{-1}\right)$. The minimum Fe concentration in grain was recorded in treatment T1 $\left(65.5 \mathrm{mg} \cdot \mathrm{kg}^{-1}\right)$, which was not statistically different from treatment $\mathrm{T} 2\left(68.6 \mathrm{mg} \cdot \mathrm{kg}^{-1}\right)$.

Table 3. Effect of biofortification on $\mathrm{Zn}$ and Fe concentration in the grain of lentil.

\begin{tabular}{|c|c|c|c|c|c|c|}
\hline \multirow{2}{*}{ Treatments } & \multicolumn{3}{|c|}{ Grain $\mathrm{Zn}$ Concentration $\left(\mathrm{mg} \cdot \mathrm{kg}^{-1}\right.$ ) } & \multicolumn{3}{|c|}{ Grain Fe Concentration $\left(\mathrm{mg} \cdot \mathrm{kg}^{-1}\right)$} \\
\hline & Year I & Year II & Mean & Year I & Year II & Mean \\
\hline $\mathrm{T} 1$ & $50.6^{\mathrm{d}} \pm 2.12$ & $60.2^{a} \pm 3.04$ & $55.9^{\mathrm{e}} \pm 2.58$ & $64.9^{\mathrm{e}} \pm 3.32$ & $66.0^{\mathrm{e}} \pm 3.13$ & $65.5^{d} \pm 3.22$ \\
\hline $\mathrm{T} 2$ & $57.1^{\mathrm{c}} \pm 2.51$ & $61.9^{\mathrm{a}} \pm 3.27$ & $59.5^{\mathrm{d}} \pm 2.89$ & $66.9^{\mathrm{de}} \pm 3.21$ & $70.3^{\mathrm{de}} \pm 3.51$ & $68.6^{\mathrm{cd}} \pm 3.36$ \\
\hline T3 & $56.2^{\mathrm{c}} \pm 2.96$ & $61.0^{a} \pm 2.98$ & $58.6^{\mathrm{d}} \pm 2.97$ & $73.1^{\mathrm{cd}} \pm 3.57$ & $74.8^{\mathrm{bcd}} \pm 3.89$ & $73.9^{b c} \pm 3.73$ \\
\hline $\mathrm{T} 4$ & $59.5^{\mathrm{ab}} \pm 3.01$ & $64.4^{\mathrm{a}} \pm 3.12$ & $62.0^{\mathrm{bc}} \pm 3.06$ & $81.1^{\mathrm{ab}} \pm 4.01$ & $76.7^{\mathrm{abc}} \pm 3.38$ & $78.9^{a b} \pm 3.69$ \\
\hline T5 & $57.8^{\mathrm{bc}} \pm 2.85$ & $68.1^{\mathrm{a}} \pm 3.37$ & $63.0^{\mathrm{b}} \pm 3.11$ & $70.5^{\text {de }} \pm 3.43$ & $72.7^{c} \pm 3.56$ & $71.6^{c} \pm 3.49$ \\
\hline T6 & $56.4^{c} \pm 2.49$ & $65.6^{\mathrm{a}} \pm 3.01$ & $61.0^{\mathrm{cd}} \pm 2.75$ & $77.0^{\mathrm{bc}} \pm 3.78$ & $78.3^{\mathrm{ab}} \pm 3.89$ & $77.6^{\mathrm{ab}} \pm 3.83$ \\
\hline $\mathrm{T} 7$ & $62.2^{\mathrm{a}} \pm 3.18$ & $70.7^{a} \pm 3.52$ & $66.4^{\mathrm{a}} \pm 3.35$ & $84.7^{\mathrm{a}} \pm 4.12$ & $81.3^{\mathrm{a}} \pm 4.02$ & $82.9^{a} \pm 4.07$ \\
\hline $\operatorname{LSD}(p \leq 0.05)$ & 2.9 & NS & 1.5 & 6.2 & 4.8 & 5.8 \\
\hline
\end{tabular}

Treatment details are available in Table 1; Year I, 2019-2020; YII, 2020-2021; The data in the table represents the mean value of three replications. The values having identical superscript letter do not differ significantly at $5 \%$ level by Duncan's Multiple Range test.

\subsection{Impact of Biofortification on Straw Zn and Fe Concentration of Lentil}

The results of two years of data concerning the $\mathrm{Zn}$ and Fe concentration in the straw of lentil with foliar application of $\mathrm{Zn}$ and Fe are given in Table 4.

Table 4. Effect of biofortification on $\mathrm{Zn}$ and Fe concentration in straw of lentil.

\begin{tabular}{|c|c|c|c|c|c|c|}
\hline \multirow{2}{*}{ Treatments } & \multicolumn{3}{|c|}{ Straw Zn Concentration $\left(\mathrm{mg} \cdot \mathrm{kg}^{-1}\right)$} & \multicolumn{3}{|c|}{ Straw Fe Concentration $\left(\mathrm{mg} \cdot \mathrm{kg}^{-1}\right)$} \\
\hline & Year I & Year II & Mean & Year I & Year II & Mean \\
\hline $\mathrm{T} 1$ & $40.4^{\mathrm{d}} \pm 2.52$ & $33.6^{\mathrm{d}} \pm 1.87$ & $37.0^{\mathrm{d}} \pm 1.05$ & $106^{\mathrm{d}} \pm 4.32$ & $126^{\mathrm{e}} \pm 5.96$ & $116^{\mathrm{d}} \pm 5.25$ \\
\hline $\mathrm{T} 2$ & $47.8^{b c} \pm 2.63$ & $43.9^{b} \pm 2.24$ & $45.9^{b} \pm 2.13$ & $119^{c} \pm 5.03$ & $139^{\text {cde }} \pm 6.36$ & $129^{c} \pm 5.84$ \\
\hline T3 & $42.4^{\mathrm{d}} \pm 2.04$ & $37.5^{\mathrm{cd}} \pm 1.96$ & $40.0^{\mathrm{cd}} \pm 1.96$ & $138^{\mathrm{b}} \pm 6.34$ & $148^{\mathrm{bcd}} \pm 7.19$ & $143^{b} \pm 6.86$ \\
\hline $\mathrm{T} 4$ & $50.1^{\mathrm{ab}} \pm 2.61$ & $44.2^{b} \pm 2.16$ & $47.2^{\mathrm{ab}} \pm 2.43$ & $145^{\mathrm{ab}} \pm 6.94$ & $150^{b c} \pm 6.98$ & $148^{\mathrm{ab}} \pm 7.52$ \\
\hline $\mathrm{T} 5$ & $48.5^{\mathrm{abc}} \pm 2.45$ & $43.2^{b} \pm 2.12$ & $45.9^{b} \pm 2.07$ & $123^{c} \pm 5.94$ & $135^{\text {de }} \pm 6.78$ & $129^{c} \pm 6.17$ \\
\hline T6 & $44.8^{c} \pm 2.16$ & $40.5^{b c} \pm 2.01$ & $42.7^{b c} \pm 2.01$ & $142^{\mathrm{ab}} \pm 7.13$ & $155^{\mathrm{ab}} \pm 7.65$ & $149^{\mathrm{ab}} \pm 7.33$ \\
\hline $\mathrm{T} 7$ & $52.9^{\mathrm{a}} \pm 2.67$ & $50.7^{\mathrm{a}} \pm 2.54$ & $51.8^{a} \pm 2.35$ & $152^{\mathrm{a}} \pm 7.37$ & $166^{\mathrm{a}} \pm 7.99$ & $159^{a} \pm 7.21$ \\
\hline $\operatorname{LSD}(p \leq 0.05)$ & 4.8 & 5.2 & 4.9 & 10 & 13 & 12 \\
\hline
\end{tabular}

Treatments detail are available in Table 1; Year I, 2019-2020; Year II, 2020-2021; The data in the table represents the mean value of three replications; the values having identical superscript letters do not differ significantly at the $5 \%$ level by Duncan's Multiple Range test.

Maximum straw Zn concentration in two years was observed in treatment T7 (51.8 $\left.\mathrm{mg} \cdot \mathrm{kg}^{-1}\right)$, which was not statistically different with treatment $\mathrm{T} 4\left(47.2 \mathrm{mg} \cdot \mathrm{kg}^{-1}\right)$. Minimum straw Zn concentration was observed in treatment $\mathrm{T} 1\left(37.0 \mathrm{mg} \cdot \mathrm{kg}^{-1}\right)$, which was not statistically different with treatment T3 $\left(40.0 \mathrm{mg} \cdot \mathrm{kg}^{-1}\right)$. Thus, foliar application of $\mathrm{FeSO}_{4} \cdot 7 \mathrm{H}_{2} \mathrm{O}(0.5 \%)$ along with RDF at $\mathrm{S} 1$ stage did not significantly affect the straw $\mathrm{Zn}$ concentration of lentil. The recorded data for Fe concentration in straw showed that treatment T7 was most effective to enhance the Fe concentration in straw $\left(159 \mathrm{mg} \cdot \mathrm{kg}^{-1}\right)$, which was not statistically different with treatment T6 $\left(149 \mathrm{mg} \cdot \mathrm{kg}^{-1}\right)$ and T4 $\left(148 \mathrm{mg} \cdot \mathrm{kg}^{-1}\right)$. The Fe concentration in straw was minimum in treatment T1 $\left(116 \mathrm{mg} \cdot \mathrm{kg}^{-1}\right)$. Thus, statistically, foliar application of 
$\mathrm{ZnSO}_{4} .7 \mathrm{H}_{2} \mathrm{O}(0.5 \%)+\mathrm{FeSO}_{4} .7 \mathrm{H}_{2} \mathrm{O}(0.5 \%)$ either applied at the $\mathrm{S} 1$ stage or $\mathrm{S} 1$ and $\mathrm{S} 2$ stages are equally effective at enhancing the $\mathrm{Zn}$ and Fe concentration of lentil in straw.

\subsection{Impact of Biofortification on Grain Zn and Fe Uptake of Lentil}

The $\mathrm{Zn}$ and Fe uptake by grain in lentil significantly increased with sole and combined use of $\mathrm{Zn}$ and Fe at different stages of growth as shown by the results presented in Table 5 .

Table 5. Effect of biofortification on $\mathrm{Zn}$ and Fe uptake in grain of lentil.

\begin{tabular}{|c|c|c|c|c|c|c|}
\hline \multirow{2}{*}{ Treatments } & \multicolumn{3}{|c|}{ Grain Zn Uptake (g.ha ${ }^{-1}$ ) } & \multicolumn{3}{|c|}{ Grain Fe Uptake $\left(g \cdot h a^{-1}\right)$} \\
\hline & Year I & Year II & Mean & Year I & Year II & Mean \\
\hline $\mathrm{T} 1$ & $34.7^{\mathrm{e}}$ & $41.4^{\mathrm{c}}$ & $38.5^{\mathrm{d}}$ & $44.5^{\mathrm{e}}$ & $45.5^{\mathrm{d}}$ & $45.1^{\mathrm{d}}$ \\
\hline $\mathrm{T} 2$ & $40.5^{\text {de }}$ & $45.8^{b c}$ & $43.1^{\mathrm{d}}$ & $47.5 \mathrm{de}$ & $52.0^{\mathrm{d}}$ & $49.7^{\mathrm{d}}$ \\
\hline T3 & $50.9^{b c}$ & $52.5^{\mathrm{b}}$ & $51.7^{\mathrm{c}}$ & $66.2^{c}$ & $64.3^{c}$ & $65.3^{c}$ \\
\hline $\mathrm{T} 4$ & $56.6^{\mathrm{ab}}$ & $62.5^{\mathrm{a}}$ & $59.6^{\mathrm{ab}}$ & $77.2^{\mathrm{ab}}$ & $74.4^{\mathrm{ab}}$ & $75.8^{a b}$ \\
\hline T5 & $45.2^{\mathrm{cd}}$ & $62.7^{\mathrm{a}}$ & $53.6^{\mathrm{bc}}$ & $55.1^{\mathrm{d}}$ & $66.9^{b}$ & $60.9^{c}$ \\
\hline T6 & $52.2 \mathrm{bc}$ & $61.7^{\mathrm{a}}$ & $56.9 \mathrm{bc}$ & $71.3^{b c}$ & $73.6^{\mathrm{ac}}$ & $72.4^{b}$ \\
\hline $\mathrm{T} 7$ & $61.8^{\mathrm{a}}$ & $69.3^{\mathrm{a}}$ & $65.5^{\mathrm{a}}$ & $84.2^{\mathrm{a}}$ & $79.7^{\mathrm{a}}$ & $81.8^{\mathrm{a}}$ \\
\hline $\operatorname{LSD}(p=0.05)$ & 7.4 & 8.4 & 7.6 & 9.6 & 6.7 & 7.0 \\
\hline
\end{tabular}

Treatment details are available in Table 1; Year I, 2019-2020; Year II, 2020-2021; The data in the table represents the mean value of three replications; the values having identical superscript letters do not differ significantly at $5 \%$ level by Duncan's Multiple Range test.

Maximum Zn uptake was recorded in treatment T7 $\left(65.5 \mathrm{~g} \cdot \mathrm{ha}^{-1}\right)$, which was not statistically different with treatment $\mathrm{T} 4\left(59.6 \mathrm{~g} \cdot \mathrm{ha}^{-1}\right)$. The least $\mathrm{Zn}$ uptake by lentil grain was observed in treatment $\mathrm{T} 1\left(38.5 \mathrm{~g} \cdot \mathrm{ha}^{-1}\right)$, which was not statistically different with treatment T2 $\left(43.1 \mathrm{~g} \cdot \mathrm{ha}^{-1}\right)$. The scrutiny of two-year data for grain Fe uptake in lentil demonstrated that the maximum Fe uptake was observed in treatment T7 $\left(81.8 \mathrm{~g} \cdot \mathrm{ha}^{-1}\right)$, and the minimum was observed in control $\left(45.1 \mathrm{~g} \cdot \mathrm{ha}^{-1}\right)$, which was not statistically different with treatment T2 $\left(49.7 \mathrm{~g} \cdot \mathrm{ha}^{-1}\right)$. Thus, foliar application of $\mathrm{ZnSO}_{4} \cdot 7 \mathrm{H}_{2} \mathrm{O}(0.5 \%)$ at $\mathrm{S} 1$ stage did not significantly affect the grain $\mathrm{Zn}$ and $\mathrm{Fe}$ uptake of lentil. Overall, foliar application of $\mathrm{ZnSO}_{4} .7 \mathrm{H}_{2} \mathrm{O}(0.5 \%)+\mathrm{FeSO}_{4} .7 \mathrm{H}_{2} \mathrm{O}(0.5 \%)$ either applied at the S1 stage or the S1 and S2 stages are equally effective at enhancing the grain $\mathrm{Zn}$ uptake in lentil.

\subsection{Impact of Biofortification on Straw Zn and Fe Uptake of Lentil}

The two-year data of $\mathrm{Zn}$ and Fe uptake by straw in lentil as affected by sole and combined foliar application of $\mathrm{Zn}$ and Fe at different growth stages has been given in Table 6. The mean data suggested that both sole $\mathrm{Zn}$ and combined $\mathrm{Zn}+\mathrm{Fe}$ application significantly enhanced the $\mathrm{Zn}$ and Fe uptake in straw over the control. The maximum $\mathrm{Zn}$ and Fe uptake by straw was observed in treatment T7 (183.3 and $562.7 \mathrm{~g} \cdot \mathrm{ha}^{-1}$, respectively) and the minimum was observed in control (183.3 and $251.3 \mathrm{~g} \cdot \mathrm{ha}^{-1}$, respectively). Thus, foliar application of $\mathrm{ZnSO}_{4} .7 \mathrm{H}_{2} \mathrm{O}(0.5 \%)+\mathrm{FeSO}_{4} \cdot 7 \mathrm{H}_{2} \mathrm{O}(0.5 \%)$ along with $\mathrm{RDF}$ at the $\mathrm{S} 1$ and $\mathrm{S} 2$ stages was most effective in enhancing the $\mathrm{Zn}$ and Fe uptake in the straw of lentil. Moreover, the micronutrient uptake was higher in the treatments in which $\mathrm{FeSO}_{4}$ ( $\mathrm{T} 3$ and T6) was applied as compared to $\mathrm{ZnSO}_{4}$ (T2 and T5). 
Table 6. Effect of biofortification on $\mathrm{Zn}$ and Fe uptake in straw of lentil.

\begin{tabular}{|c|c|c|c|c|c|c|}
\hline \multirow{2}{*}{ Treatments } & \multicolumn{3}{|c|}{ Straw Zn uptake $\left(g \cdot h a^{-1}\right)$} & \multicolumn{3}{|c|}{ Straw Fe uptake $\left(g \cdot h a^{-1}\right)$} \\
\hline & Year I & Year II & Mean & Year I & Year II & Mean \\
\hline $\mathrm{T} 1$ & $86.4^{\mathrm{f}}$ & $73.7^{\mathrm{e}}$ & $80.2^{\mathrm{e}}$ & $226.7^{\mathrm{e}}$ & $276.5^{\mathrm{e}}$ & $251.3^{\mathrm{e}}$ \\
\hline $\mathrm{T} 2$ & $108.8^{\mathrm{e}}$ & $112.4^{\mathrm{cd}}$ & $110.9^{d}$ & $271.0^{\mathrm{de}}$ & $355.8^{d}$ & $311.7^{\mathrm{d}}$ \\
\hline $\mathrm{T} 3$ & $123.7^{\mathrm{de}}$ & $104.3^{\mathrm{d}}$ & $114.0^{\mathrm{d}}$ & $402.7^{\mathrm{c}}$ & $411.4^{\mathrm{cd}}$ & $407.4^{\mathrm{C}}$ \\
\hline $\mathrm{T} 4$ & $164.8^{\mathrm{b}}$ & $145.0^{\mathrm{b}}$ & $155.3^{\mathrm{b}}$ & $476.8^{\mathrm{b}}$ & $492.0^{\mathrm{b}}$ & $486.8^{b}$ \\
\hline $\mathrm{T} 5$ & $119.3^{\mathrm{e}}$ & $126.4^{\mathrm{bcd}}$ & $123.6^{\mathrm{cd}}$ & $302.5^{\mathrm{d}}$ & $394.9^{\mathrm{d}}$ & $347.3^{d}$ \\
\hline $\mathrm{T} 6$ & $143.6^{\mathrm{cd}}$ & $136.5^{b c}$ & $140.4^{b c}$ & $455.3^{\mathrm{b}}$ & $522.4^{\mathrm{ab}}$ & $489.9^{b}$ \\
\hline $\mathrm{T} 7$ & $190.9^{a}$ & $175.9^{\mathrm{a}}$ & $183.3^{\mathrm{a}}$ & $548.6^{\mathrm{a}}$ & $575.8^{a}$ & $562.7^{\mathrm{a}}$ \\
\hline $\operatorname{LSD}(p \leq 0.05)$ & 20.2 & 26.5 & 24.5 & 45.5 & 55.6 & 48.8 \\
\hline
\end{tabular}

Treatments detail are available in Table 1; Year I, 2019-2020; Year II, 2020-2021; The data in table represents the mean value of three replications; the values having identical superscript letters do not differ significantly at $5 \%$ level by Duncan's Multiple Range test.

\subsection{Impact of Biofortification on Efficiency Indices of Lentil}

The results of Table 7 demonstrated that the MEI-Zn was highest in treatment T1 (1.51) and lowest in treatment T2 (1.31) which showed that the external supply of Zn has more of an effect on straw $\mathrm{Zn}$ concentration as compared to grain $\mathrm{Zn}$ concentration. The apparent recovery efficiency of $\mathrm{Zn}$ (ARE-Zn) was highest in treatment T2 (10.0) and lowest in treatment T3 (4.56), whereas ARE-Fe was at its maximum in treatment T3 (28.3) and its minimum in treatment T2 (12.9). The results of PE-Zn were highest for treatment T3 (18.7) and least in treatment T2 (8.20), whereas PE-Fe was at its maximum in treatment T5 (7.18) and its minimum in treatment $\mathrm{T} 2$ (4.77).

Table 7. Effect biofortification on efficiency indices of lentil.

\begin{tabular}{ccccccc}
\hline Treatments & MEI-Zn & MEI-Fe & ARE-Zn & ARE-Fe & PE-Zn & PE-Fe \\
\hline T1 & 1.51 & 0.56 & - & - & - & - \\
T2 & 1.30 & 0.53 & 10.0 & 12.9 & 8.20 & 4.77 \\
T3 & 1.47 & 0.52 & 4.56 & 28.3 & 18.7 & 5.62 \\
T4 & 1.31 & 0.53 & 6.52 & 18.2 & 14.6 & 6.14 \\
T5 & 1.37 & 0.56 & 6.4 & 7.6 & 11.8 & 7.18 \\
T6 & 1.43 & 0.52 & 4.32 & 18.0 & 17.4 & 5.73 \\
T7 & 1.28 & 0.52 & 5.06 & 12.1 & 13.0 & 5.69 \\
\hline
\end{tabular}

Treatments details are available in Table 1.

\subsection{Economic Analysis}

The economic analysis of lentil cultivation as affected by foliar application of $\mathrm{ZnSO}_{4}$ and $\mathrm{FeSO}_{4}$ is shown in Figure 2. The data indicated that the cultivation cost was maximum for treatment T7 (\$455) and minimum in control (\$396). The highest net return was recorded for treatment T4 (\$409) followed by T7 (\$402). The benefit:cost ratio (B:C) ratio was highest recorded in treatment T4 (1.96) followed by T7 (1.88) and least in treatment T1 (1.51) 


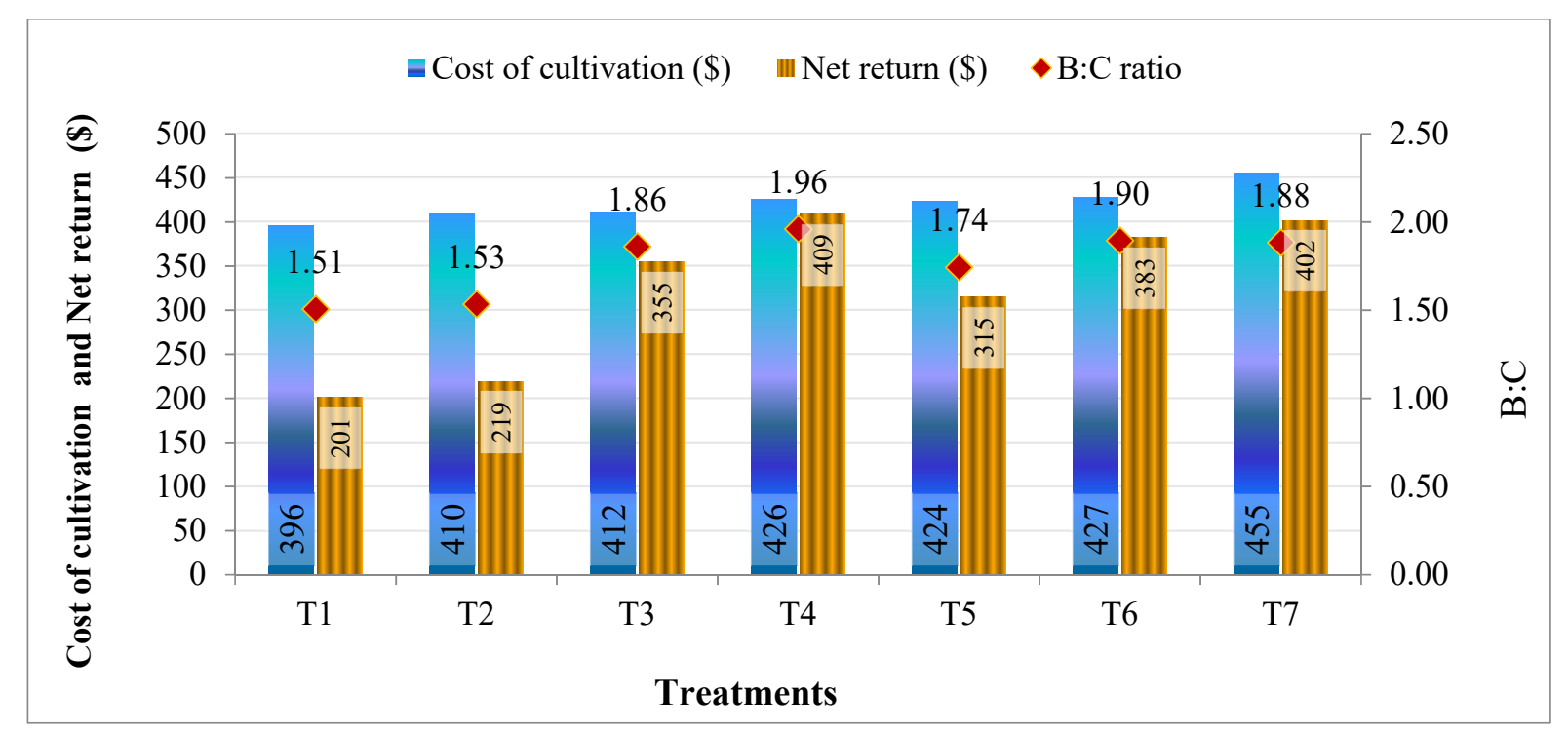

Figure 2. Effect of $\mathrm{Zn}$ and Fe biofortification on cost of cultivation, net returns and economic analysis of lentil. Treatment details are available in Table 1.

\section{Discussion}

\subsection{Grain and Straw Yield}

Grain yield is a crucial parameter of the crop grown for commercial purposes. The results of Table 3 indicate that the combined application of $\mathrm{ZnSO}_{4} \cdot 7 \mathrm{H}_{2} \mathrm{O}(0.5 \%)+\mathrm{FeSO}_{4} \cdot 7 \mathrm{H}_{2} \mathrm{O}$ $(0.5 \%)$ either at $\mathrm{S} 1$ or at the $\mathrm{S} 1$ and $\mathrm{S} 2$ stages significantly increased the grain yield of lentils, which might be ascribed to the synergistic interactions between $\mathrm{Zn}$ and Fe. Zinc acts as an important structural component of various enzymes involved in the metabolism of plant growth and yield component. Zinc also plays a crucial role in sugar and protein synthesis as well as seed production. Zinc application to lentil at the reproductive phase might have induced the structural and functional alterations in pollen grains and stigma of the plants, thus increasing the seed setting of lentils in contrast to unfertilized plots [32]. Another possible reason could be the fostered photosynthetic rate and translocation of photosynthetic products to the grain with Zn application, which resulted in higher enzymatic activity and thus grain and straw yield [33]. Thus, foliar application of $\mathrm{Zn}$ results in its facile absorption and transportation within the plant body and improves the grain and straw yield. The higher grain and straw yield with exogenous Fe supply during the reproductive phase can be explained in association with the elevated carbohydrates and protein synthesis and their transportation towards the site of grain production. Also, the increase in Fe might have increased the activation of several enzymes, as it is a structural constituent of several enzymes involved in photosynthesis such as ferredoxin and cytochromes [34]. Apart from that, Fe encourages the seed maturation, metabolism of nucleic acid and synthesis of growth promoter molecules like auxins [33]. In good agreement with this, the increase in grain yield of several other crops has been reported in a number of previous research endeavors [23,33]. Habib recorded the highest wheat yield with a combined application of $\mathrm{Zn}$ and $\mathrm{Fe}$ as compared to the sole application of these nutrients [34]. Likewise, the combined application of $0.5 \% \mathrm{ZnSO}_{4} .7 \mathrm{H}_{2} \mathrm{O}$ and $0.5 \% \mathrm{FeSO}_{4} .7 \mathrm{H}_{2} \mathrm{O}$ was found to be more effective at increasing the grain and straw yield of chickpea as compared to the sole application of $\mathrm{Zn}$ and Fe. Moreover, the treatment in which fertilizers were applied at the pre-flowering and pod-formation stages was more effective as compared to the treatment when fertilizers were applied only at the pre-flowering stage [35].

\subsection{Zn and Fe Concentration}

Although the micronutrient ( $\mathrm{Zn}$ and $\mathrm{Fe}$ ) requirement of the crop is very small, yet it is essential for optimum plant growth. Foliar application of $\mathrm{Zn}$ (single or double spray) 
resulted in higher $\mathrm{Zn}$ concentrations in the grain and straw of lentil in comparison to untreated plants, which might be ascribed to the immediate absorption of $\mathrm{Zn}$ by plant leaves as the nutrient spray is directed toward the leaves. Higher $\mathrm{Zn}$ concentration in grain and straw with two Zn sprays over the single Zn spray was associated with higher $\mathrm{Zn}$ availability through two sprays. For instance, foliar application of micronutrients in oilseed crops at the S1 and S2 stages has resulted in a significant increase in micronutrient concentration in the edible part of the crop [36]. Another possible reason might be the suppression of the antinutrient (phytate) due to which bioavailable Zn concentration increased [31]. Similar results were observed for the Fe concentration in grain and in the straw of lentil. Higher Fe concentration in straw than grain might be associated with the presence of Fe storage proteins and non-heme proteins, which have a high binding capacity for Fe. In concordance with the present results, the combined application of $\mathrm{Zn}$ and Fe was found to be a superior treatment in enhancing $\mathrm{Zn}$ and Fe concentration in wheat as compared to the sole application of these nutrients [34]. In Indian mustard, the combined application of $0.5 \% \mathrm{ZnSO}_{4} .7 \mathrm{H}_{2} \mathrm{O}$ and $0.5 \% \mathrm{FeSO}_{4} \cdot 7 \mathrm{H}_{2} \mathrm{O}$ was found to be more effective to increase the $\mathrm{Zn}$ and Fe concentration as compared to the sole application of $\mathrm{Zn}$ and Fe. Moreover, the treatment involving the fertilizer application at pre-flowering and pod-formation stages was more effective as compared to the single spray of fertilizers at the pre-flowering stage of Indian mustard [37].

\subsection{Zn and Fe Uptake}

The results of the study showed that micronutrient ( $\mathrm{Zn}$ and Fe) uptake has been found to increase significantly with external supplementation. The trend can be coupled with the combined effect of yield and concentration. Overall, the combined application of $\mathrm{ZnSO}_{4}+\mathrm{FeSO}_{4}$ was most effective at increasing the uptake of $\mathrm{Zn}$ and $\mathrm{Fe}$ in grain and straw. Moreover, the $\mathrm{Zn}$ and Fe uptake was higher with foliar Fe application as compared to the foliar $\mathrm{Zn}$ application due to significantly higher yield with Fe supplementation.

\subsection{Efficiency Indices and Economic Analysis}

The agronomic efficiency reflects the impact of fertilizer applied on economic returns. The trend suggested that the application of $0.5 \% \mathrm{FeSO}_{4}$ at the $\mathrm{S} 1$ and $\mathrm{S} 2$ stages is most effective at increasing the lentil production as compared to the $\mathrm{ZnSO}_{4}(0.5 \%)$ and $\mathrm{ZnSO}_{4} .7 \mathrm{H}_{2} \mathrm{O}$ $(0.5 \%)+\mathrm{FeSO}_{4} .7 \mathrm{H}_{2} \mathrm{O}(0.5 \%)$. The results of MEI indicated that the MEI of $\mathrm{Zn}$ and $\mathrm{Fe}$ were higher in control and the values were higher for MEI-Zn as compared to MEI-Fe, which suggests higher mobility of $\mathrm{Zn}$ as compared to Fe. The ARE measured the extent of nutrient loss from the cropping system and effectiveness of management practices. The results suggested that foliar application of a particular nutrient is effective in overcoming the nutrient losses. The results of PE indicate the increase in grain production with the absorbed nutrient. The higher values PE- $\mathrm{Zn}$ and PE-Fe were observed in treatment where the $\mathrm{FeSO}_{4}$ was applied as compared to the treatment in which $\mathrm{ZnSO}_{4}$ was applied. A similar increase in efficiency indices has also been observed in Indian mustard with $\mathrm{Zn}$ and Fe application [37].

The results of the economic analysis indicated that the application of $\mathrm{ZnSO}_{4} \cdot 7 \mathrm{H}_{2} \mathrm{O}$ and $\mathrm{FeSO}_{4} .7 \mathrm{H}_{2} \mathrm{O}$ improved the economic outcomes of lentil cultivation. The results are in alignment with previous studies, where micronutrient application has increased the $\mathrm{B}: \mathrm{C}$ ratio of sesame cultivation [31]. Also, the two sprays of $\mathrm{ZnSO}_{4} \cdot 7 \mathrm{H}_{2} \mathrm{O}(0.5 \%)+\mathrm{FeSO}_{4} \cdot 7 \mathrm{H}_{2} \mathrm{O}(0.5 \%)$ is more effective over the single spray. Moreover, the combined application of $\mathrm{ZnSO}_{4} .7 \mathrm{H}_{2} \mathrm{O}$ $(0.5 \%)+\mathrm{FeSO}_{4} .7 \mathrm{H}_{2} \mathrm{O}(0.5 \%)$ is more effective over the sole application of nutrients. In agreement with the present results, the combined application of $0.5 \% \mathrm{ZnSO}_{4} .7 \mathrm{H}_{2} \mathrm{O}$ and $0.5 \% \mathrm{FeSO}_{4} .7 \mathrm{H}_{2} \mathrm{O}$ was found to be more profitable as compared to the sole application of $\mathrm{Zn}$ and Fe for chickpea cultivation. Moreover, the double spray of $0.5 \% \mathrm{ZnSO}_{4} .7 \mathrm{H}_{2} \mathrm{O}+$ $0.5 \% \mathrm{FeSO}_{4} .7 \mathrm{H}_{2} \mathrm{O}$ at the pre-flowering and pod-formation stages was found to be more economical as compared to the single spray of $0.5 \% \mathrm{ZnSO}_{4} \cdot 7 \mathrm{H}_{2} \mathrm{O}$ and $0.5 \% \mathrm{FeSO}_{4} .7 \mathrm{H}_{2} \mathrm{O}$ at the pre-flowering stage of chickpea [30]. 


\section{Conclusions}

Lentil (Lens culinaris Medik) is a leguminous crop predominantly grown in Asia whose productivity can be influenced by the application of micronutrients in order to enhance their availability to consumers worldwide. The combined foliar application of $\mathrm{Zn}$ and $\mathrm{Fe}$ through $\mathrm{ZnSO}_{4} \cdot 7 \mathrm{H}_{2} \mathrm{O}(0.5 \%)+\mathrm{FeSO}_{4} \cdot 7 \mathrm{H}_{2} \mathrm{O}(0.5 \%)$ at the pre-flowering + pod formation stages was found to be efficient in improving the grain and straw yield, $\mathrm{Zn}$ and Fe concentration and uptake, apparent recovery efficiency and benefit:cost ratio. The results of foliar application of $\mathrm{ZnSO}_{4} .7 \mathrm{H}_{2} \mathrm{O}(0.5 \%)+\mathrm{FeSO}_{4} .7 \mathrm{H}_{2} \mathrm{O}(0.5 \%)$ at the pre-flowering + pod formation stages were statistically at par with the results obtained at the pre-flowering stage. Thus, the present study points towards the potential application of $\mathrm{ZnSO}_{4} \cdot 7 \mathrm{H}_{2} \mathrm{O}$ $(0.5 \%)+\mathrm{FeSO}_{4} .7 \mathrm{H}_{2} \mathrm{O}(0.5 \%)$ at the pre-flowering stages as the most effective treatment for enhancing yield, nutrient concentration and economic returns of lentil grown in sandy loam soils in northwestern India. In sum, dual-biofortified lentil can contribute significantly in increasing the bioavailability of $\mathrm{Zn}$ and Fe to the population at risk of $\mathrm{Zn}$ and Fe deficiency.

Author Contributions: Conceptualization, S.S.D., V.S., A.K.S., V.V., P.S., J.K. and H.S.; methodology, S.S.D., V.S., A.K.S., V.V., P.S., J.K. and H.S.; software, S.S.D. and A.H.; validation, S.S.D., V.S., A.K.S., V.V., P.S., J.K. and H.S.; formal analysis, S.S.D. and A.H.; investigation, S.S.D., V.S., A.K.S., V.V., P.S., J.K. and H.S.; resources, S.S.D. and A.H.; data curation, S.S.D. and A.H.; writing-original draft preparation, S.S.D., V.S., A.K.S., V.V., P.S., J.K. and H.S.; writing-review and editing, S.H.A.-H., A.G., S.S., R.A. and A.H.; visualization, S.S.D., V.S., A.K.S., V.V., P.S., J.K. and H.S.; supervision, S.S.D.; project administration, S.S.D., S.H.A.-H., A.G., S.S. and A.H.; funding acquisition, S.H.A.-H., A.G., S.S., R.A. and A.H. All authors have read and agreed to the published version of the manuscript.

Funding: This research publication was funded by the Taif University Researchers for funding this research with Supporting Project number (TURSP-2020/23), Taif University, Taif, Saudi Arabia.

Institutional Review Board Statement: Not applicable.

Informed Consent Statement: Not applicable.

Data Availability Statement: All data are available in the manuscripts.

Acknowledgments: Authors gratefully thank Taif University Research Supporting Project number (TURSP-2020/23), Taif University, Taif, Saudi Arabia, for supporting this publication.

Conflicts of Interest: The authors declare no conflict of interest.

Sample Availability: Samples of the compounds $\left(\mathrm{ZnSO}_{4} \cdot 7 \mathrm{H}_{2} \mathrm{O}\right.$ and $\left.\mathrm{FeSO}_{4} \cdot 7 \mathrm{H}_{2} \mathrm{O}\right)$ are available from the authors.

\section{References}

1. Tuso, P.J.; Ismail, M.H.; Ha, B.P.; Bartolotto, C. Nutritional update for physicians: Plant-based diets. Perm. J. 2013, 17, 61-66. [CrossRef] [PubMed]

2. DellaValle, D.M.; Thavarajah, D.; Thavarajah, P.; Vandenberg, A.; Glahn, R.P. Lentil (Lens culinaris L.) as a candidate crop for iron biofortification: Is there genetic potential for iron bioavailability? Field Crop. Res. 2013, 144, 119-125. [CrossRef]

3. Thavarajah, D.; Thavarajah, P.; Sarker, A.; Vandenberg, A. Lentils (Lens culinaris Medikus Subspecies culinaris): A whole food for increased iron and zinc intake. J. Agric. Food Chem. 2009, 57, 5413-5419. [CrossRef] [PubMed]

4. Kumar, J.; Thavarajah, D.; Kumar, S.; Sarker, A.; Singh, N.P. Analysis of genetic variability and genotype 3 environment interactions for iron and zinc content among diverse genotypes of lentil. J. Food Sci. Technol. 2018, 55, 3592-3605. [CrossRef] [PubMed]

5. Singh, A.; Sharma, V.K.; Dikshit, H.K.; Singh, D.; Aski, M.; Prakash, P.; Kaushik, S.C.; Singh, G.; Kumar, S.; Sarker, A. Microsatellite marker-based genetic diversity analysis of elite lentil lines differing in grain iron and zinc concentration. J. Plant Biochem. Biotechnol. 2016, 26, 199-207. [CrossRef]

6. Grusak, M.A. Nutritional health-beneficial quality. In The Lentil: Botany, Production Uses; Erskine, W., Muehlbauer, F.J., Sarker, A., Sharma, B., Eds.; CABI International: Cambridge, MA, USA, 2009; pp. 368-390.

7. Thavarajah, D.; Thavarajah, P.; Wejesuriya, A.; Rutzke, M.; Glahn, R.P.; Combs, G.F. The potential of lentil (Lens culinaris L.) as a whole food for increased selenium, iron, and zinc intake: Preliminary results from a 3 year study. Euphytica 2011, 180, 123-128. [CrossRef]

8. Reddy, N.R. Occurance, distribution, content dietary intake of phytate. In Food Phytates; Rukma, R.N., Shridhar, S.K., Eds.; CRC Press: London, UK, 2001; pp. 25-51. 
9. Hurrell, R.F.; Juillerat, M.A.; Reddy, M.B.; Lynch, S.R.; Dassenko, S.A.; Cook, J.D. Soy protein, phytate, and iron absorption in humans. Am. J. Clin. Nutr. 1992, 56, 573-578. [CrossRef]

10. Saunders, A.V.; Craig, W.J.; Baines, S.K. Zinc and vegetarian diets. Med. J. Aust. 2013, 199, 17-21. [CrossRef]

11. Young, I.; Parker, H.M.; Rangan, A.; Prvan, T.; Cook, R.L.; Donges, C.E. Association between haem and non-haem iron intake and serum Ferritin in healthy young women. Nutrients 2018, 10, 81. [CrossRef]

12. Shukla, A.K.; Behera, S.K.; Prakash, C.; Tripathi, A.; Patra, A.K.; Dwivedi, B.S.; Trivedi, V.; Rao, C.S.; Chaudhari, S.K.; Das, S.; et al. Deficiency of phyto-available sulphur, zinc, boron, iron, copper and manganese in soils of India. Sci. Rep. 2021, 11, 19760. [CrossRef]

13. Bailey, R.L.; West, K.P.; Black, R.E. The epidemiology of global micronutrient deficiencies. Ann. Nutr. Metab. 2015, 66, 22-33. [CrossRef]

14. Wessells, K.R.; Brown, K.H. Estimating the global prevalence of zinc deficiency: Results based on zinc availability in national food supplies and the prevalence of stunting. PLoS ONE 2012, 7, e0050568. [CrossRef]

15. Allen, L.; de Benoist, B.; Dary, O.; Hurrell, R. Guidelines on Food Fortification with Micronutrients. 2006. Available online: https:/ / www.who.int/nutrition (accessed on 14 October 2021).

16. Ritchie, H.; Roser, M. Micronutrient deficiency. Our World in Data. 2020. Available online: https:/ / ourworldindata.org (accessed on 14 October 2021).

17. World Health Organization. The Global Prevalence of Anaemia in 2011. Available online: https://www.who.int/nutrition/ publications /micronutrients/global_prevalence_anaemia_2011/en/(accessed on 14 October 2021).

18. Boccio, J.R.; Iyengar, V. Iron deficiency: Causes, consequences, and strategies to overcome this nutritional problem. Biol. Trace Elem. Res. 2003, 94, 1-32. [CrossRef]

19. White, P.J.; Broadley, M.R. Biofortifying crops with essential mineral elements. Trends Plant Sci. 2005, 10, 588-593. [CrossRef]

20. Combs, G.F.; Duxbury, J.M.; Welch, R.M. Food systems for improved health: Linking agricultural production and human nutrition. Eur. J. Clin. Nutr. 1997, 51, 32-33.

21. Welch, R.M. Breeding strategies for biofortified staple plant foods to reduce micronutrient malnutrition globally. J. Nutr. 2002, 132, 495S-499S. [CrossRef] [PubMed]

22. Pfeiffer, W.H.; McClafferty, B. Harvest Plus: Breeding crops for better nutrition. Crop Sci. 2007, 47, 89-105. [CrossRef]

23. Dhaliwal, S.S.; Sadana, U.S.; Manchanda, J.S.; Dhadli, H.S. Biofortification of wheat grains with zinc and iron in Typic Ustochrept soils of Punjab. Indian J. Fert. 2009, 5, 13-20.

24. Dhaliwal, S.S.; Ram, H.; Shukla, A.K.; Mavi, G.S. Zinc biofortification of bread wheat, triticale, and durum wheat cultivars by foliar zinc fertilization. J. Plant Nutr. 2019, 42, 813-822. [CrossRef]

25. Rahman, M.; Erskine, W.; Materne, M.; Mcmurray, L.; Thavrajah, P.; Thavarajah, D.; Siddique, K. Enhancing selenium concentration in lentil (Lens culinaris subsp. Culinaris) through foliar application. J. Agric. Sci. 2015, 153, 656-665; [CrossRef]

26. Haider, M.U.; Hussain, M.; Farooq, M.; Ul-Allah, S.; Ansari, M.J.; Alwahibi, M.S. Zinc biofortification potential of diverse mungbean [Vigna radiata (L.) Wilczek] genotypes under field conditions. PLoS ONE 2021, 16, e0253085. [CrossRef] [PubMed]

27. Fang, Y.; Wang, L.; Xin, Z.; Zhao, L.; An, X.; Hu, Q. Effect of foliar application of zinc, selenium, and iron fertilizers on nutrients concentration and yield of rice grain in China. J. Agric. Food Chem. 2008, 56, 2079-2084. [CrossRef] [PubMed]

28. Singh, A.K.; Bhatt, B.P. Late-sown lentil performance in response to foliar application of zinc. Bangladesh J. Bot. 2015, 44, 125-128. [CrossRef]

29. Sadeghi, S.; Noorhosseini, S.A. Evaluation of foliar application effects on Zn and Fe on yield and its components of lentil (Lens culinaris, Medik), Iran. Indian J. Fund. Appl. Life Sci. 2014, 4, 220-225.

30. Kumar, B.; Dhaliwal, S.S. Zinc biofortification of dual purpose cowpea [Vigna unguiculata (L.) Walp.] for enhancing the productivity and nutritional quality in a semi-arid regions of India. Arch. Agron. Soil Sci. 2021, 67, 1-15. [CrossRef]

31. Khampuang, K.; Lordkaew, S.; Dell, B.; Prom-u-thai, C. Foliar zinc application improved grain zinc accumulation and bioavailable zinc in unpolished and polished rice. Plant Prod. Sci. 2021, 24, 94-102. [CrossRef]

32. Pandey, N.; Pathak, G.C.; Sharma, C.P. Zinc is critically required for pollen function and fertilisation in lentil. J. Trace Elem. Med. Biol. 2006, 20, 89-96; [CrossRef] [PubMed]

33. Pal, V.; Singh, G.; Dhaliwal, S.S. Agronomic biofortification of chickpea with zinc and iron through application of zinc and urea. Comm. Soil Sci. Plant Anal. 2019, 50, 1864-1877. [CrossRef]

34. Habib, M. Effect of foliar application of Zn and Fe on wheat yield and quality. Afr. J. Biotechnol. 2009, 8, 6795-6798.

35. Dhaliwal, S.S.; Sharma, V.; Shukla, A.K.; Verma, V.; Behera, S.K.; Singh, P.; Alotaibi, S.S.; Gaber, A.; Hossain, A. Comparative Efficiency of Mineral, Chelated and Nano Forms of Zinc and Iron for Improvement of Zinc and Iron in Chickpea (Cicer arietinum L.) through Biofortification. Agronomy 2021, 11, 2436. [CrossRef]

36. Dhaliwal, S.S.; Sharma, V.; Shukla, A.K.; Verma, V.; Behera, S.K.; Sandhu, P.S.; Kaur, K.; Gaber, A.; Althobaiti, Y.S.; Abdelhadi, A.A.; et al. Assessment of agroeconomic indicators of Sesamum indicum L. as influenced by application of boron at different levels and plant growth stages. Molecules 2021, 26, 6699. [CrossRef] [PubMed]

37. Dhaliwal, S.S.; Sharma, V.; Shukla, A.K.; Verma, V.; Sandhu, P.S.; Behera, S.K.; Singh, P.; Kaur, J.; Singh, H.; Abdel-Hafez, S.H.; et al. Interactive Effects of Foliar Application of Zinc, Iron and Nitrogen on Productivity and Nutritional Quality of Indian Mustard (Brassica juncea L.). Agronomy 2021, 11, 2333. [CrossRef] 